\title{
Wang Hui, The Politics of Imagining Asia
}

Edited by Theodore Huters, Cambridge (MA), Harvard University Press, 2011, 360 pp.

\section{Émilie Frenkiel}

Translator. N. Jayaram

\section{OpenEdition}

\section{Journals}

\section{Electronic version}

URL: http://journals.openedition.org/chinaperspectives/6057

DOI: 10.4000/chinaperspectives.6057

ISSN: 1996-4617

\section{Publisher}

Centre d'étude français sur la Chine contemporaine

\section{Printed version}

Date of publication: 7 December 2012

Number of pages: $75-76$

ISSN: 2070-3449

\section{Electronic reference}

Émilie Frenkiel, « Wang Hui, The Politics of Imagining Asia », China Perspectives [Online], 2012/4 | 2012,

Online since 01 December 2012, connection on 10 December 2020. URL : http://

journals.openedition.org/chinaperspectives/6057; DOI : https://doi.org/10.4000/chinaperspectives. 6057

This text was automatically generated on 10 December 2020 .

(c) All rights reserved 


\section{Wang Hui, The Politics of Imagining Asia}

Edited by Theodore Huters, Cambridge (MA), Harvard University Press, 2011, 360 pp.

\section{Émilie Frenkiel}

Translation : N. Jayaram

1 This substantive work representing Wang Hui's intellectual engagement is the second that Harvard University Press has published by this professor of Chinese language and literature at Tsinghua University, following China's New Order: Society, Politics and Economy in Transition (2003). In 2009, Verso published his The End of the Revolution: China and the Limits of Modernity. Like the other two, The Politics of Imagining Asia is a collection of translated essays published between 1998 and 2008. The first three in the book under review were published in English language journals before publication in China. Wang's focus in this book is less on contemporary social and economic problems than on historic questions, although some recent events such as the Tibetan riots of Spring 2008 are analysed.

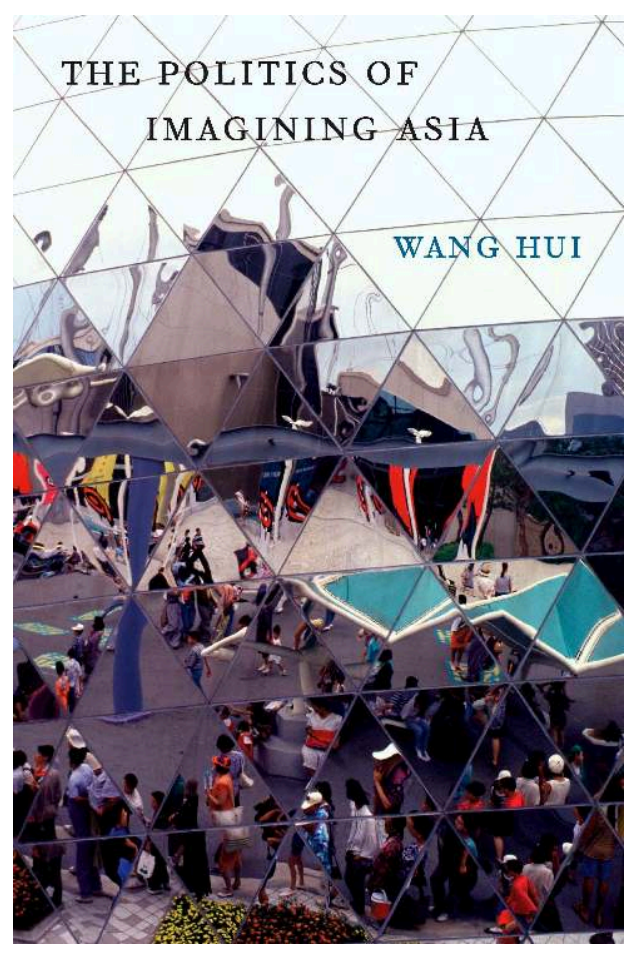

2 The book's aim is to study and place in context "Western" discourses from which descriptions and analyses of china were elaborated during the twentieth century. It thus follows the systematic approach of this best known member of China's New Left, who seeks to offer an alternative vision of 
history and Chinese "modernity" freed of the baggage of Western thought, which has long dominated representations of China and its history. For Wang, "modern" is a temporal concept used discriminatingly to cast other periods out of the modern; in this sense, "modern" is a discriminatory concept, rejecting all other elements present in the same space-time, and having established a "hegemonic hierarchical structure." It should be noted that while Wang's studies of modern literature, especially of Lu Xun, have been standard-setting, ${ }^{,}$it is due to his published work on intellectual history and criticisms of liberalism, consumerism, globalisation, and imperialism that he has gained fame in China and abroad.

3 The influence of Edward Saïd (invoked in a long polemical essay on Western representations of Tibet), Jacques Derrida, and Dipesh Chakrabarty are readily apparent in the first essay in the collection, "The politics of imagining Asia," as well as in others devoted to Chinese modernity ("How to explain 'China' and its 'modernity': Rethinking The rise of modern Chinese thought" and "Weber and the question of Chinese modernity"), to discussion of dialects and the national language ("Local forms, vernacular dialects, and the War of Resistance against Japan: The 'national forms' debate"), to the Tibet issue ("The 'Tibetan question' East and West: Orientalism, regional ethnic autonomy, and the politics of dignity"), and to the tribute system, especially between Okinawa and China ("Okinawa and the two dramatic changes to the regional order"). Wang Hui sets out to deconstruct the way in which foreign thinkers and scholars have conceptualised Asia (p. 16), in an attempt at revising world history, provincialising Europe, and challenging the universality and relevance of the nationstate concept (p.60), but also encouraging China'sempowerment and agency over its own history. These essays are difficult to crack, rich in detail and often unexpected references. They describe a determined struggle for discursive equality and for the right to criticise Western theories on an equal footing with Western theoreticians, taking into account another "political culture," especially that of China (and notably its imperial history, tributary system, defence of "unity in diversity" opposed to ethnic nationalism, etc.). The book also denounces Eurocentrism, defined as the imposition of supposedly universal rules but established to respond to European needs and interests (p. 260), and mounts a struggle for liberating the concept of China as well as for complex ways of seeing:

I examine the entity of 'China' and its implications from various angles in order to liberate the concept from a simplistic notion of European nationalism. "China" is a richer, more flexible and more diverse category than the concept of the national would imply (...) (p. 78)

4 Wang's approach is not only part of the New Left but also part of more general and recent attempts at a patriotic revision of history and of Chinese "tradition" and indigenisation (bentuhua) of Western resources. It is thus clear from the various essays that Wang Hui considers Asian and Chinese historic experience as a resource for a radical change in theory and practice - based on a new self-awareness ("this new selfknowledge of Chinese society," p. 227) as opposed to the "clash of ignorance" (p. 255) - and as a means to open up to alternative models inspired by the past as well as to redefine the modernisation process so as to achieve a democratisation that precludes social polarisation and disintegration.

5 The essay on Tibet is a good illustration of this. With a patriotic flourish, Wang describes the demand for Tibet's independence as a product of orientalism and Western realpolitik, mixed with idealisation of Tibetan spirituality. He relies on recently opened 
CIA archives on Tibet from the 1950s and on his 2001 visit to an exhibition entitled "Dreamworld Tibet-Western and Chinese Phantoms" mounted at the Zurich anthropological museum by noted ethnologist and Tibetologist Martin Brauer, who has undertaken to elucidate the reasons for his fascination for this region of the world in particular. Wang's aim is to demonstrate the legitimacy of Chinese claims to Tibet, his argument based on the idea that China's modern sovereignty over Tibet is founded on various pre-modern forms of political relations, including the tributary system that had been in place for centuries. More convincingly, the final part of the chapter devoted to the multi-cultural and multinational state stresses the linkages between many of the problems Tibet confronts and those that affect other parts of China, mainly rising inequalities, social and cultural commercialisation and depoliticisation, cultural impoverishment, and transformation of lifestyles thanks to globalisation. Wang says the ethnic factor does indeed complicate the situation but that it is not the only explanation for Tibet's crisis (p. 196). He holds that instead of demanding merely formal individual equality, the emphasis should be on ensuring that modern society attaches the same importance to protecting collective rights, especially those of ethnic minorities, women, and immigrants. He says that while China's positive discrimination policy towards ethnic minorities recognises the difference and the importance of collective rights, it is driven by a formal vision of equality and an essentialisation of the difference. A genuine recognition of difference should on the contrary translate into a predisposition "toward diversity and equality as well as toward further association, coexistence, and mixing among divergent ethnicities" (p. 223).

6 This is an engaging and ambitious book in which it is easy to get lost, such is the abundance of its resources and references. Nevertheless, its aim, while clear and consistent, is not entirely achieved. It may be noted that while the author demands a re-appropriation of Chinese history by his compatriots, references to Chinese concepts and works are quite rare in his book, and whereas he rightly criticises the binary opposition between the East and the West, he fails to depart from it.

\section{NOTES}

1. Wang Hui, “'Zhongguo zhizao' yu lingleide xiandaixing” (Made in China and another modernity), Zhuangshi zazhi, 181, May 2008. Cited in Xu Jilin, "Valeurs universelles ou valeurs chinoises? Le courant de pensée de l'historicisme dans la Chine contemporaine" (Universal values or Chinese values? The current of historicism thought in China today), Rue Descartes, no. 72, 2011/2012, p. 55.

2. In 2010 , he was accused of plagiarism, especially as regards his literary works. However, these allegations made by liberal personalities and journals had no effect on his career. 


\section{AUTHORS}

ÉMILIE FRENKIEL

PhD from EHESS (CESPRA), and ATER of political science at the University of Paris 8

(anmingli@gmail.com). 